\title{
LINGKUNGAN VEGETASI SITUS PERCANDIAN PADANG LAWAS DAN TUMBUHAN BALAKA
}

\author{
Arfian \\ (Pusat Penelitian Dan Pengembangan Arkeologi Nasional) \\ Email: arfiansofyan@yahoo.com
}

\begin{abstract}
ABSTRAK
Dari hasil penelitian tentang lingkungan vegetasi di sekitar komplek percandian Padang Lawas, Kabupaten Padang Lawas, Provinsi Sumatera Utara, diketahui bahwa komplek percandian Padang lawas berada dalam lingkungan vegetasi hutan hujan tropik dataran rendah dengan tingkat kanekaragaman jenis famili tumbuhan yang tinggi, salah satu diantara famili tumbuhan tersebut adalah Euphorbiaceae dengan salah satu spesiesnya Phylanthus emlica. L (Balaka). Tumbuhan Phylanthus emlica merupakan tumbuhan liar di tempat-tempat terbuka dalam hutan hujan tropik dataran rendah. Mengamati sifat hidup dan habitatnya, maka tumbuhnya Balaka (Phylanthus emlica) pada pekarangan-pekarangan candi di Padang Lawas kemungkinan bukan sengaja ditanam melainkan tumbuh secara alami.

Tumbuhan Balaka (Phylanthus emlica) di daerah lain dikenal dengan nama daerahnya masing-masing, di Melayu dikenal dengan malaka, di Minangkabau dikenal dengan balaka, di Sunda dikenal dengan nama malaka dan di Jawa dikenal dengan Kemloko sementara itu di Madura dan Bali disebut dengan mlakah, dan Flores (NTT) dikenal dengan karsinta.
\end{abstract}

Kata Kunci : Ekosistem, Vegetasi, Balaka, Candi.

\section{ENVIRONMENT VEGETATION PADANG LAWAS TEMPLE SITES AND BALAKA PLANTS}

\begin{abstract}
Based on the results of research on the vegetation around Padang Lawas Temples, Padang Lawas Regency, North Sumatera Province, can be known that Padang Lawas Temple sites are located in vegetation environment of lowland tropical rain forest with a high level diversity of plant families, one of those plant families is Euphorbiaceae with one of its species, Phylanthus emlica. L(Balaka). Phylanthus emlica is a type wild plant that grows open spaces in lowland tropical rain forests. Observing its life characteristic and its habitat, then Balaka plant (Phylanthus emlica) in Padang Lawas Temples' yards was not planted in purpose planted but grows naturally.
\end{abstract}


Balaka plant (Phylanthus emlica) has different name in every area. In Melayu, this plant is known as malaka. In Minangkabau known as balaka, in Sunda known as malaka and in Java, this plant is known as Kemloko, meanwhile in Madura and Bali this plant is called mlakah , and karsinta in Flores (NTT)

Keywords: Ecosystem, Vegetation, Balaka, Temple

\section{PENDAHULUAN}

Situs percandian Padang Lawas, merupakan peninggalan masa Klasik Indonesia yang terdapat di Daerah Aliran Sungai Barumun dan Sungai Pane. Secara adiministratif persebaran bangunan-bangunan situs pecandian di Padang Lawas berada dalam dua wilayah kabupaten yaitu wilayah Kabupaten Padang Lawas dan Kabupaten Mandailing Natal. Diantara kedua kabupaten ini, persebaran bangunan candi yang paling banyak ditemukan di daerah di Kabupaten Padang Lawas yang berjarak lebih kurang $400 \mathrm{Km}$ dari Kota Medan dengan kondisi jalan yang cukup baik.

Sukawati Susetyo (2006) mengatakan bahwa situs-situs di Padang Lawas berada dalam suatu areal dengan luas sekitar $1500 \mathrm{~km} 2$, di tepi Sungai Barumun, Pane dan anak-anak sungainya. Situs-situs yang terdapat di Batang (sungai) Pane dimulai dari tepian hulu adalah Situs Gunung Tua, Si Topayan, Hayuara, Haloban, Rondaman, Bara, Pulo, Bahal I, Bahal 2 dan Bahal 3, sedangkan di tepian Sungai Sirumambe terdapat situs Batu Gana, Si Soldop, Padangbujur, Nagasaribu, dan Mangaledang, sementara situs-situs di tepian Sungai Barumun adalah Pangeranbira, Pordak dolok, $\mathrm{Si}$ Sangkilon, Tandikat 1, Tandikat 2 dan Si Pamutung. Tulisan mengenai percandian Padang Lawas pertama kali diperoleh dari beberapa peneliti asing antara lain Franz Junghun (1846), Von Rosenberg (1854), Kerkhoff (1887), PV. Van Stein Callenfels (1920), NJ Krom (1923), dan beberapa orang peneliti lainnya. Menurut Suleiman (1985), biaro-biaro (candi-candi) di Padang Lawas dibangun bersamaan dengan stupa-stupa di Muara Takus pada tahun 825 Masehi dan berdasarkan pertulisan-pertulisan singkat yang ditemukan di situs-situs biaro Padang Lawas, maka Suleiman berpendapat bahwa Biaro-biaro (candi-candi) di Padang Lawas dibangun pada abad ke 11 - 14 Masehi.

Penelitian tentang kepurbakalaan situs Padang Lawas telah dilakukan sejak tahun 1953 oleh Dinas Purbakala, dan kemudian dilanjutkan oleh Lembaga Purbakala dan Peninggalan Nasional bekerjasama dengan The University of Pensylvania Museum pada tahun 1973 dan 1975. Penelitian oleh Pusat Penelitian Arkeologi Nasional dilakukan tahun 1993, 1994,1995, 2002, 2006 dan 2009, dari hasil penelitian-penelitian tersebut telah diperoleh hasil tentang adanya perubahan yang dialami oleh Sungai Pane dan Barumun yang dikarenakan oleh tingkat erosi yang cukup tinggi, 
dan dari hasil eskavasi di situs Tandihat II telah ditemukan pula bentuk dan ukuran denah bangunan candi, arah hadap tangga naik serta telah ditemukannya beberapa artefak bai berupa arca, pecahan keramik maupun temuan arkeologi lainnya. Kantor Wilayah Departemen Pendidikan Dan Kebudayaan Provinsi Sumatera Utara juga telah melakukan pendataan dan inventarisasi tinggalan budaya di Padang Lawas pada tahun 1994, serta penelitian-penelitian Balai Arkeologi Medan tahun 1994, 1995 dan 2001.

Dari hasil penelitian-penelitian tersebut, disamping temuan bangunan candi (biaro) juga telah ditemukan berbagai benda arkeologis lainnya baik berupa arca batu dan perunggu, komponen bangunan candi, pecahan gerabah dan keramik. Semua temuan-temuan tersebut menunjukkan bahwa daerah Padang Lawas telah dihuni oleh manusia pada masa klasik terutama sebagai tempat peribadatan dan kemungkinan juga sebagai tempat permukiman rumah tinggal.

Dipilihnya daerah ini sebagai tempat bermukim tentu disebabkan oleh adanya faktor lingkungan alam yang menunjang kehidupan mereka pada masa itu. Butzer (1972) mengatakan variabel lingkungan alam yang menentukan dalam pemilihan suatu daerah sebagai tempat bermukim oleh manusia adalah tersedianya kebutuhan akan sumber air bersih, tersedianya sumber makanan baik flora maupun fauna dan kemudahan untuk memperoleh bahan makanan serta tersedianya kebutuhan akan fasilitas untuk bergerak (pantai, hutan dan sungai). Apakah variabel-variabel lingkungan alam sebagaimana yang dikatakan Butzer tersebut terdapat di lingkungan percandian Padang Lawas?, hal ini perlu diketahui untuk melengkapi data hasil penelitian arkeologi yang telah dilakukan.

Disamping itu dalam tulisan ini juga akan diuraikan tentang adanya anggapan masyarakat Padang Lawas terutama masyarakat yang bermukim di sekitar daerah percandian terhadap satu jenis tumbuhan yang menurut mereka hanya dapat tumbuh di lahan perkarangan candi. Sampai saat ini di setiap lahan perkarangan candi Padang lawas tumbuhan tersebut tumbuh dengan subur sementara di luar lahan perkarangan candi tidak dapat tumbuh ataupun tumbuh dengan sangat merana, sehingga mereka menyebutnya dengan "tumbuhan candi" yang kemudian mereka kenal dengan nama "Balaka" tapi anggapan bahwa tumbuhan tersebut hanya dapat hidup di lahan perkarangan candi masih terus berkembang, anggapan masyarakat seperti itu perlu diteliti kebenarannya agar mereka memperoleh suatu pengertian yang pasti. Kalimat terlalu panjang.

\section{LINGKUNGAN VEGETASI}

Secara fisiografi daerah Padang Lawas termasuk dalam wilayah "Lipatan Bagian Timur Pulau Sumatera", wilayah lipatan bagian timur ini agak lebih landai jika dibandingkan dengan wilayah lipatan bagian barat, curah hujan tahunan di wilayah ini lebih kurang 2000 mm (Sandy, 1985). 
Situs-situs arkeologi yang terdapat di daerah Padang Lawas, secara umum terdapat pada daerah-daerah yang memiliki ketinggian antara 50 300 meter dari atas permukaan laut. Secara fisiognomi atau kenampakan luar interaksi antara tumbuh-tumbuhan dan hewan dengan lingkungan disekitarnya, maka vegetasi yang hidup di daerah Padang Lawas termasuk dalam bentuk vegetasi pamah darat (lowland vegetation). Menurut Didin S Sastrapradja dkk (1989) vegetasi pamah adalah kelompok vegetasi yang hidup pada elevasi 0 - 1000 meter dari atas permukaan laut, kelompok vegetasi ini terdiri atas vegetasi rawa dan vegetasi darat dan merupakan sebagian besar hutan serta mencakup kawasan yang paling luas di Indonesia.

Secara umum, dari pengamatan yang dilakukan terhadap jenis-jenis tumbuhan pamah yang hidup di daerah Padang Lawas dapat diketahui bahwa lingkungan vegetasi di daerah ini disusun oleh beraneka jenis tumbuhan yang berasal dari berbagai famili (marga) yang antara lain terdiri dari jenis famili Euphorbiaceae (jarak-jarakan), Anacardiaceae (manggamanggaan), Verbenaceae (jati-jatian), Arecaceae (pinang-pinangan), Dipterocarpaceae (meranti-merantian), Moraceae (beringin-beringan), Meliaceae (duku-dukuan), Lecythidaceae (putat-putatan), Sapindaceae (rambutan-rambutanan), Myrtaceae (jambu-jambuan), Musaceae (pisangpisangan), Myristicaceae (pala-palaan) dan beberapa jenis dari famili lain. Dalam lingkungan vegetasi ini juga ditemukan beberapa jenis tumbuhan memanjat dan tumbuhan epihit. Berdasarkan jenis famili tumbuhan, dan ketinggian daerah Padang Lawas yang hanya berkisar $50-300$ meter dari atas pemukaan laut, maka lingkungan vegetasi di daerah Padang Lawas termasuk dalam tipe ekosistem "Hutan hujan tropik dataran rendah". Menurut Anthony J Whitten dkk (1987) dan Syahbuddin (1985) bahwa ekosistem Hutan hujan tropik dataran rendah, khususnya di daerah-daerah lembab atau daerah dengan curah hujan yang cukup tinggi, dicirikan oleh adanya tumbuhan memanjat, pohon-pohon berbanir dan meratanya pohonpohon tinggi dengan batang pokok yang mempunyai kelika yang licin. Sebagian besar pohon-pohon mempunyai daun tunggal dengan mesophil yang panjangnya antara 8 sampai $24 \mathrm{~cm}$. Daun pohon dengan tajuk yang lebih rendah termasuk individu-individu pohon-pohon besar yang belum dewasa sering mempunyai daun yang lebih besar. Pohon-pohon yang tajuknya lebih rendah pada umumnya mempunyai daun dengan ujung daun penetes. Hasil pemetaan tipe hutan yang dilakukan oleh para ahli berhasil memetakan bahwa hutan hujan tropik dataran rendah ( Hutan basah selalu hijau) tumbuh di bawah ketinggian $1200 \mathrm{~m}$ dari atas permukaan laut, dimana curah hujan melebihi $2000 \mathrm{~mm}$, dan bulan basahnya kurang dari dua bulan, serta dicirikan oleh adanya jenis pohon dari famili Moraceae, Meliaceae dan Lecythidaceae.

Pada masa kini, lingkungan vegetasi dari ekosistem hutan hujan tropik dataran rendah yang terdapat di sekitar situs Padang Lawas sudah mengalami gangguan manusia, karena adanya pemanfaatan lahan terutama pada lahan-lahan yang relatif datar untuk areal pemukiman dan 
usaha pertanian baik berupa persawahan yang biasa ditanamai dengan padi (Oryza sativa), dan perladangan yang ditanami dengan tumbuhan semusim (annual plant), maupun berupa perkebunan yang ditanami dengan tumbuhan berusia panjang (perennial plant). Akan tetapi gangguan tersebut tidaklah mengakibatkan terjadinya perubahan pada ekosistem di daerah ini secara menyeluruh, karena jenis tumbuhan yang dijadikan bentuk usaha pertanian oleh masyarakat masih merupakan jenis-jenis dari famili tumbuhan yang memang hidup dalam lingkungan vegetasi hutan hujan tropik dataran rendah, perubahan yang terjadi pada lahan-lahan yang telah diusahakan oleh masyarakat hanyalah pengurangan tingkat keanekaragaman jenis tumbuhan. Hutan hujan dataran rendah yang relatif belum dimanfaatkan oleh masyarakat pada masa kini hanya dijumpai pada daerah-daerah perbukitan yang jauh dari pemukiman masyarakat.

Dari pengamatan yang dilakukan di sekitar situs-situs percandian yang terdapat di Padang Lawas yang meliputi Candi Bahal I, Candi Bahal II, Candi Bahal III, Candi Pulo, Candi Sangkilon, Candi Tandihat I, Candi Tandihat II, Candi Tandihat III, Candi Sitopayan, Candi Sipamutung, Candi Pulo dan Candi Nagasaribu serta beberapa situs lain seperti Situs Pagaranbira, Situs Mangaledang dan Situs Nagasaribu, telah terjadi pemanfaatan lahan untuk perkebunan terutama perkebunan kelapa sawit (Elaeis guineensis, fam Arecaceae) dan karet (Hevea brasilliensis, fam Euphorbiaceae) serta pemukiman. Dengan dibukanya lahan sekitar situs untuk areal perkebunan tersebut, maka pada masa kini situs-situs percandian dan beberapa situs lain yang terdapat di daerah Padang Lawas seakan-akan berada di pinggir atau di tengah-tengah areal perkebunan kelapa sawit, perkebunan karet, perkebunan kopi, dan jati. Di daerah Padang Lawas jenis tanaman perkebunan karet dan kelapa sawit dapat tumbuh dan berkembang dengan baik karena faktor lingkungan alam terutama kondisi fisik tanah dan ketinggian tempat serta rata-rata curah hujan tahunan, di daerah ini $( \pm 2000 \mathrm{~mm})$ dapat menunjang pertumbuhannya. Menurut Wisaksono (1953) tumbuhan karet (Hevea brasilliensis) dan kelapa sawit (Elaeis guineensis) merupakan golongan tanaman dataran rendah tropis yang dapat tumbuh dengan baik pada daerah-daerah dengan ketinggiannya tidak lebih dari 500 meter dari atas permukaan laut. Pertumbuhan karet yang terbaik ditemukan pada daerah dengan ketinggian kurang dari 200 meter dari atas permukaan laut dengan derajat panas rata-rata tidak kurang dari $24^{\circ} \mathrm{C}$ dan rata-rata curah hujan tahunannya tidak kurang dari $2000 \mathrm{~mm}$. Adapun kelapa sawit pada umumnya dapat tumbuh dengan baik pada semua bentuk tubuh tanah yang dapat dipergunakan untuk tanaman perusahaan pada daerah dengan ketinggian tidak lebih dari 500 meter dari atas permukaan laut. 

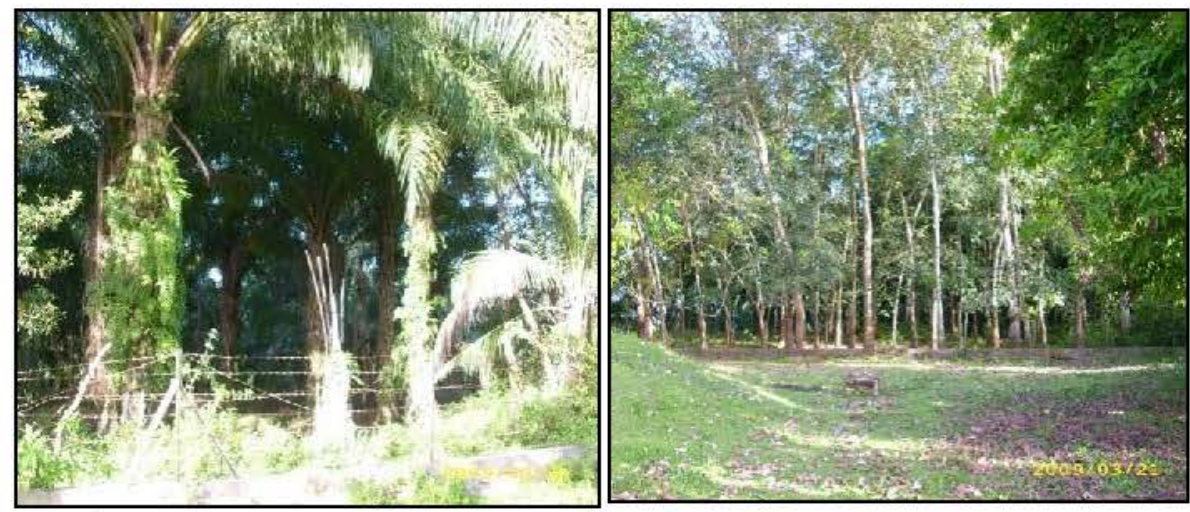

1

2

Foto 1: Salah satu lingkungan perkebuman kelapa sawit (Elaeis gwineersais) di Padang Lawas. (Dok Arfiar, 2009)

Foto 2: Salah satu lingkumgan perkeburan karet (Heven brasilfienvis) di Padang Lawas. (Dok Arfian, 2009)

Jazanul Anwar (1984) mengatakan bahwa kelapa sawit dan karet merupakan dua tanaman perkebunan di Sumatera. Tanaman perkebunan ini memiliki sifat-sifat ekologik yang agak berbeda, tanaman karet tidak toleran terhadap tanah rawa, sedangkan tanaman kelapa sawit toleran terhadap tanah rawa dan tidak toleran terhadap tanah kering. Akan tetapi tanaman kelapa sawit yang dibudidayakan sekarang ini telah toleran terhadap tanah yang lebih kering. Oleh karena itu, hampir tidak ada sisa hutan yang dapat bertahan di dalam satu perkebunan kelapa sawit, karena semua lokasinya dapat dimanfaatkan untuk perkebunan kelapa sawit. Berdasarkan pengamatan yang dilakukan terhadap lokasi-lokasi perkebunan kelapa sawit yang terdapat di Padang Lawas, tampak bahwa penanaman kelapa sawit tidak hanya dilakukan di tanah kering, tetapi juga ditemukan di tanah rawa, sebagaimana yang terdapat di rawa bekas sungai purba dekat candi Bahal II dan III, serta di rawa-rawa di tempat lain yang terdapat di daerah Padang Lawas.

Bentuk perkebunan lain yang tidak begitu luas diusahakan oleh masyarakat adalah perkebunan jati (Tectona grandis, fam Verbenaceae), kopi (Coffea arabica, fam Rubiaceae), pinang (Areca sp, fam Arecaceae). Menurut informasi masyarakat tidak luasnya usaha perkebunan dari ketiga jenis tanaman tersebut dikarenakan kurangnya minat masyarakat. Hal tersebut dikarenakan kurang cocoknya kondisi fisik tanah di daerah ini untuk tanaman kopi dan jati, sehingga untuk menghasilkan perkebunan yang baik, harus dikelola dengan modal yang besar karena harus dilakukan pemupukan. Kurangnya minat masyarakat tersebut pada perkebunan pinang dikarenakan harga jual rendah jika dibandingkan dengan harga jual kelapa sawit dan jual getah pohon karet. Informasi masyarakat ini ada benarnya juga, karena menurut Wisaksono (1953) tanaman kopi dapat tumbuh dengan baik pada daerah dengan ketinggian antara $1000-1700$ meter dari atas permukaan laut dengan derajat panas antara $16^{\circ} \mathrm{C}-20^{\circ} \mathrm{C}$ 
dan yang lebih penting curah hujannya merata sepanjang tahun dengan curah hujan minimal antara $1500-2000 \mathrm{~mm}$ pertahunnya. Selain itu, memiliki iklim kemarau yang tegas, sedangkan tanaman jati dan pinang walaupun dapat tumbuh pada tubuh tanah apa pun juga pada daerah dengan ketinggian $0-1000$ meter dari atas permukaan laut, tetapi kedua tanaman tersebut sangat membutuhkan struktur tubuh tanah yang baik.

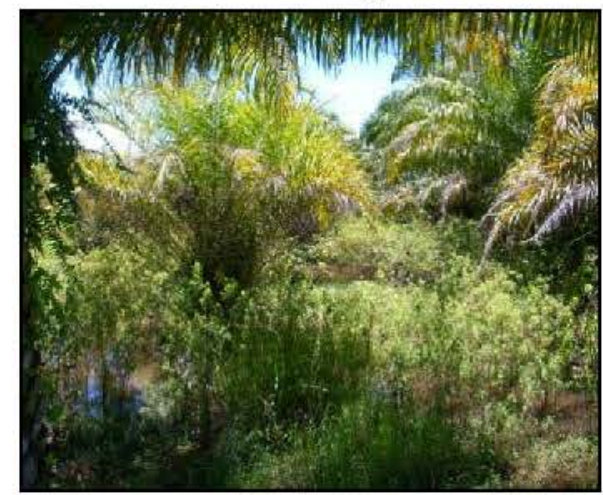

3

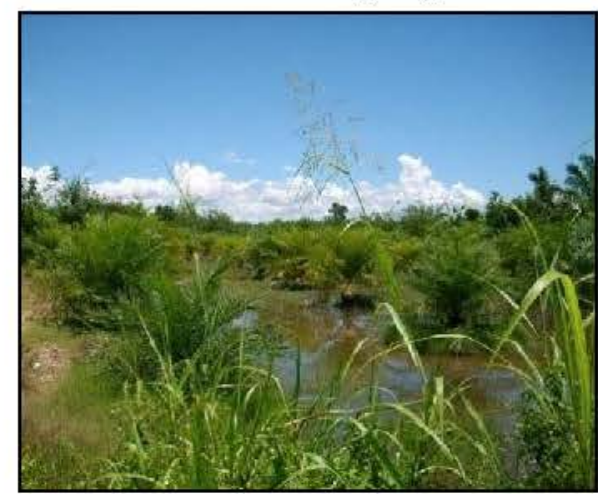

4

Foto 3. Salah satu lingkungan perkebunan kelapa sawit (Elaeis gumeerais) di tanah rawa dekat candi Bahal II (Dok Arfiar, 2009)

Foto 4. Salah satu lingkungan perkebunan kelapa sawit (Elaeis gurineensis) di tanah rawa dekat candi Bahal III. (Dok Arfian, 2009)

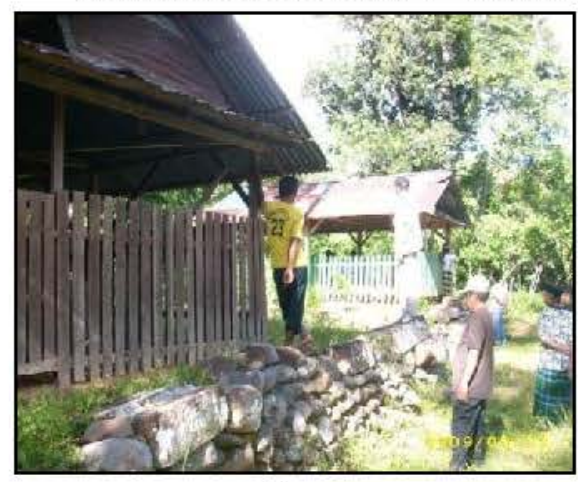

5

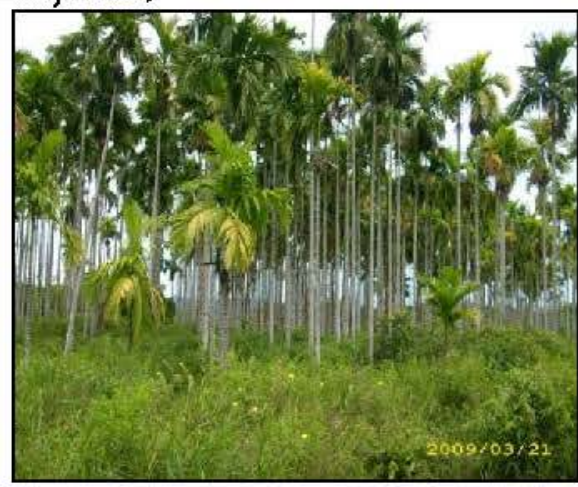

6

Foto 5. Perkebunan kopi di sekitar situs Pangaranbira di Kecamatan Sosopan (Dok Arfian, 2009)

Foto 6. Salah satix perkebrunm pinang yang terdapat di daerah Padang Lawas. (Dok Arfian, 2009)

Di antara tanaman-tanaman perkebunan di atas, di sekitar situs dan pemukiman masyarakat masih dijumpai jenis-jenis tumbuhan lain baik tumbuhan buah-buahan atau tumbuhan lain yang berbentuk pohon seperti mangga (Mangifera sp, fam Anacardiaceae), lontar (Borassus flabelifer, fam Arecaceae), kemboja (Plumeria acuminata, fam Apocynaceae), balaka (Phyllanthus emblica, fam Euphorbiaceae), kelapa (Cocos nucifera, fam Arecaceae), jambu biji (Psidium guajava, fam Myrtaceae), waru (Hibiscus tiliaceus, fam Malvaceae), duku (Lancium domesticum, fam Meliaceae), 
belimbing wuluh (Averoa bilimbi, fam Oxalidaceae), jambu air (Syzygium aqueum, fam Myrtaceae), rambutan (Nephelium lappaceum, fam Sapindaceae), pisang (Musa paradisiaca, fam Musaceae), kemiri (Aleurites moluceana, fam Euphorbiaceae), nangka (Arthocarpus integra, fam Moraceae), Bambu (Denrocalamus asper, fam Poaceae) dan beberapa jenis dari famili tumbuhan lainnya.

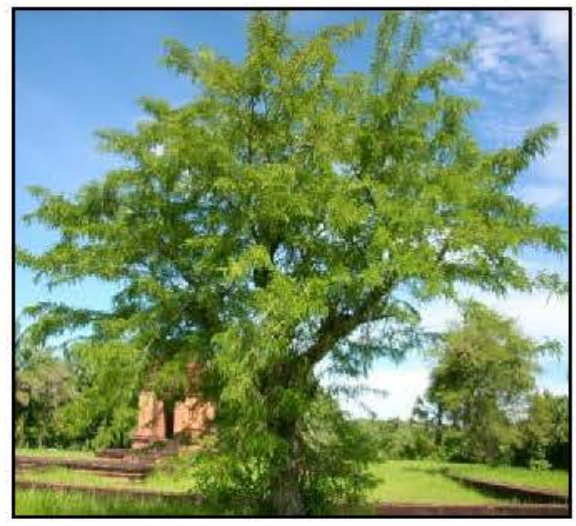

7

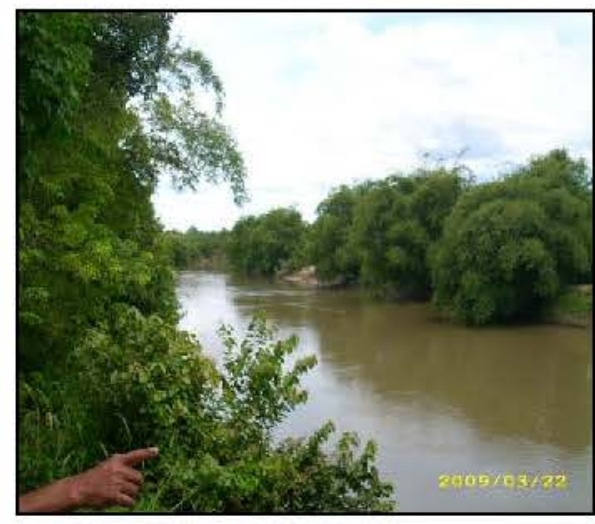

8

Foto 7. Balaka (Phyllanthus emblica) salah satu jenis tumbuhan yang selalu diternakan hidup di setiap halaman candi di daerah Padang Lawas. (Dok Arfian, 2009)

Foto 8. Rumpun-rumpun bambu (Derrocalamus apper) dipinggir sungai Paneyang dapat mencirikan adanya gangguan yang berulang-ulang di daerah ini. (Dok Arfiom, 2009)

Berdasarkan pengamatan yang dilakukan terhadap jenis-jenis tumbuhan pada lingkungan vegetasi, ketinggian daerah di bawah 300 meter dari atas permukaan laut, serta kondisi iklim terutama curah hujan di sekitar situs percandian Padang Lawas, menunjukkan tidak terjadi perubahan ekosistem daerah tersebut. Oleh karena itu besar kemungkinan tipe ekosistem pada masa situs percandian tersebut masih berfungsi sama dengan ekosistem masa kini yaitu ekosistem hutan hujan tropis dataran rendah. Perbedaan yang terjadi berupa pengurangan jenis tumbuhan pada daerah-daerah yang dimanfaatkan oleh masyarakat, sedangkan pada daerah-daerah perbukitan masih mencerminkan tingkat keanekaragaman jenis tumbuhan yang tinggi.

Tingginya tingkat keanekaragaman jenis famili tumbuhan dalam ekosistem ini menunjukkan bahwa lingkungan vegetasi ini merupakan daerah subur yang dialiri oleh sungai-sungai besar seperti Sungai Barumun, Pane, dan anak-anak sungainya, kondisi alam seperti inilah yang mungkin menyebabkan dipilihnya daerah Padang Lawas sebagai tempat bermukim oleh manusia pada masa lampau. 


\section{TUMBUHAN BALAKA}

Berdasarkan pengamatan terhadap lingkungan vegetasi di daerah sekitar situs percandian Padang Lawas, diketahui bahwa hampir di setiap pekarangan candi yang meliputi Candi Bahal I, Candi Bahal II, Candi Bahal III, Candi Pulo, Candi Sangkilon, Candi Tandihat I, Candi Tandihat II, Candi Tandihat III, Candi Pulo, Candi Sipamutung, dan Candi Nagasaribu ditemukan sejenis pohon buah-buahan yang oleh masyarakat setempat dikenal dengan tumbuhan balaka. Tumbuhan ini merupakan tumbuhan berkayu, batang bulat, dengan kulit batang berwarna coklat keputihan, tinggi batang bervariasi antara $5-12$ meter, memiliki daun majemuk berbentuk lonjong, buah bulat berada diketiak daun berwama kuning terang dengan rasa agak pahit dan asam.

Identifikasi dan determinasi yang dilakukan dengan mempergunakan buku kunci "Taksonomi Tumbuhan (Spermatophyta)" cetakan ke 4, yang disusun oleh Gembong Tjitrosoepomo (1993), dan "Daftar Nama Tumbuhan oleh J.J Afriastini (1989), maka diketahui bahwa tumbuhan Balaka tersebut secara sistematik termasuk dalam

$\begin{array}{lll}\text { Divisio } \quad: & \text { Angiospermae } \\ \text { Sub Divisio : } & \text { Dicotyledon } \\ \text { Kelas } \quad \vdots & \text { Euphorbiales } \\ \text { Famili } \quad & \text { Euphorbiaceae } \\ \text { Genus (suku) : } & \text { Phylanthus } \\ \text { Spesies : } & \text { Phylanthus emlica.L }\end{array}$

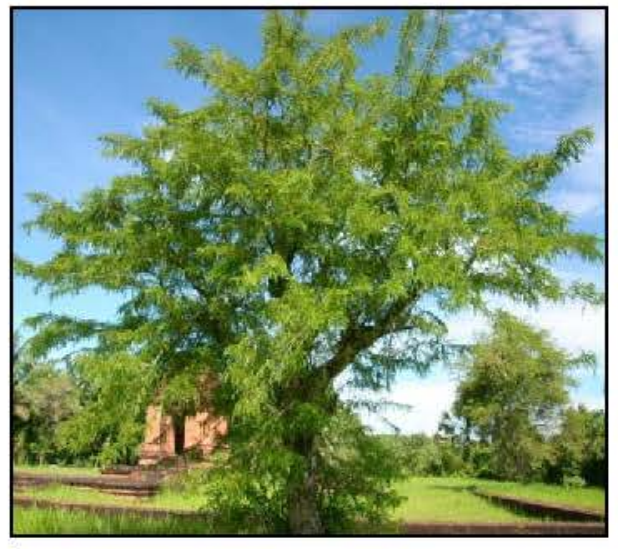

9

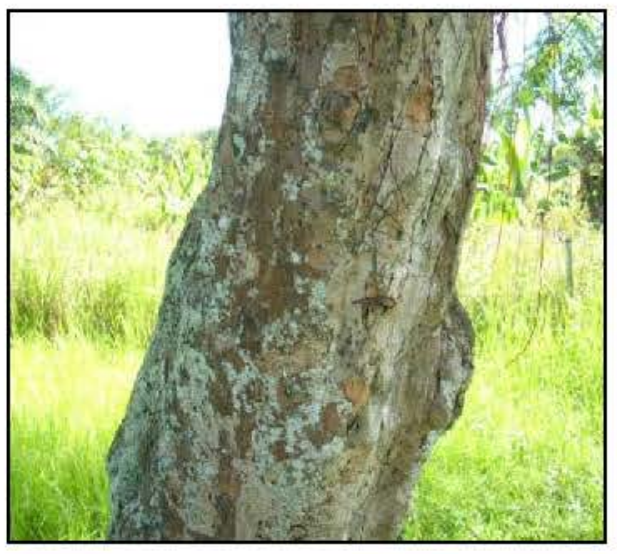

10

Foto 9. Bentuk morfologi tumbuhhon balala (Phylanthess emfics). (Dok Arfian, 2009)

Foto 10. Bentuk morfologi dari batang pohon balaka (Phylanthus emtica). (Dok Arfian, 2009) 


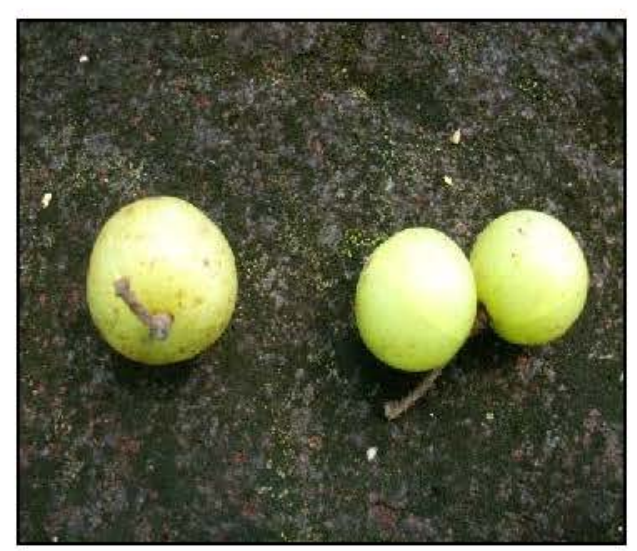

II

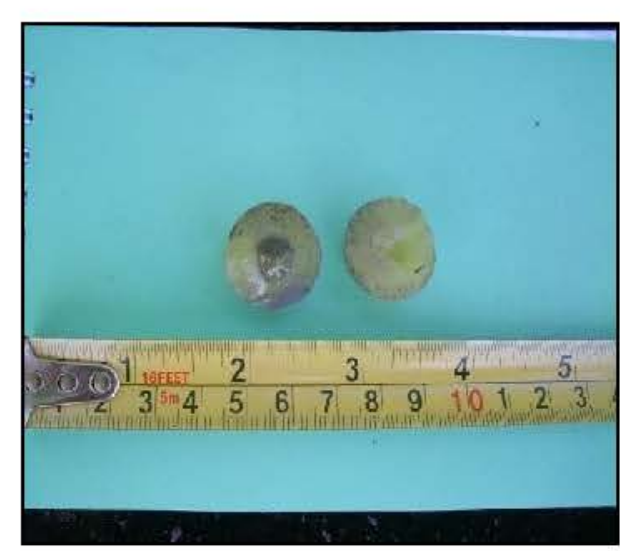

12

Foto 11. Bentuk dan warra buah dari tumbuhan balaka (Fhydanthus emtion). (Dok Arfian, 2009)

Foto 12. Penampang lintang buah balaka (Phylunthrs entica). (Dok Arfian, 2009)

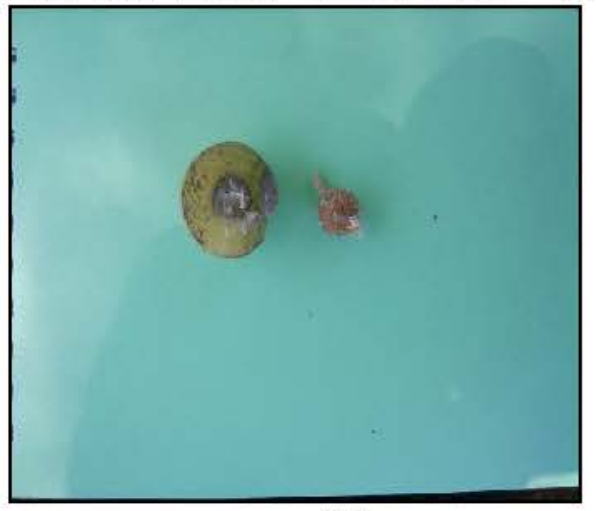

13

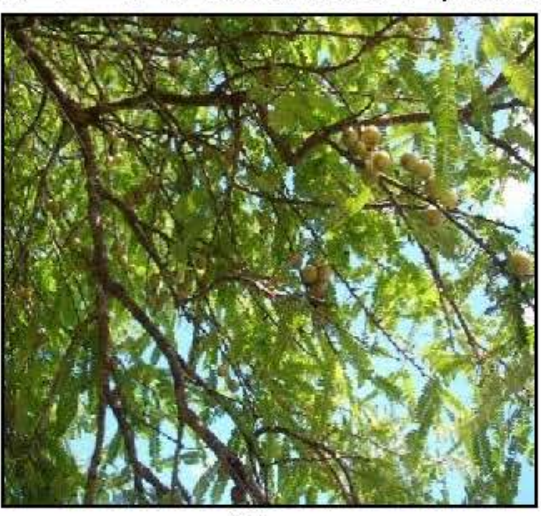

14

Foto 13. Penampang lintang buah dan bentuk biji yang bulat lonjong dengan warna coklat dari tumbuhan balaka (Phylanthus entios). (Dok Arfian, 2009)

Foto 14. Kedudukan buah dan daun pada batang pohon balaka (Phylenthus emtica). (Dok Arfiam, 2009)

Tumbuhan Phylanthus emlica hidup tersebar di Asia Tenggara, ditemukan hidup liar di hutan hujan basah, ladang-ladang dan tempat lain yang berhawa panas. Hidup berupa pohon dengan tinggi batang dapat mencapai 10 - 19 meter, dan berdiameter antara 15 sampai dengan $28 \mathrm{~cm}$, berbatang bulat dengan percabangan monopodial, kayu berwarna coklat keputihan. Daun ditumbuhi oleh bulu-bulu kecil, pendek dan mengeluarkan aroma seperti lemon, daun majemuk berbentuk lonjong dengan pangkal dan ujung daun meruncing serta berwama hijau. Panjang daun antara $14-22$ $\mathrm{mm}$ dan lebar $3,5 \mathrm{~mm}$ dengan pertulangan menyirip hijau. Tumbuhan ini berbunga tunggal, kecil, berbentuk bulat diketiak daun dengan panjang 5-6 $\mathrm{mm}$, berkelamin ganda. Buah dari tumbuhan ini tunggal, terdapat diketiak 
daun berbentuk bundar, berwarna kuning pucat dengan diameter sekitar 2 $\mathrm{cm}$. Biji buah lonjong, keras berwarna coklat muda (Syahbuddin, !985).

Di Indonesia jenis tumbuhan Phylanthus emlica juga ditemukan pada beberapa daerah lain dengan nama daerah yang berbeda-beda dimana di daerah Melayu dikenal dengan malaka, di Minangkabau dikenal dengan balaka, sedangkan di Sunda orang mengenalnya dengan nama malaka dan di Jawa dikenal dengan Kemloko, sementara itu di Madura dan Bali disebut dengan mlakah, dan Flores (NTT) dikenal dengan karsinta. Mengamati nama daerah tumbuhan Phyllanthus emlica di daerah Padang Lawas dikenal dengan nama balaka, maka besar kemungkinan nama balaka di daerah Padang Lawas ini dipengaruhi oleh nama daerah tumbuhan tersebut di Minangkabau.

Mengamati sifat hidup dan persebaran tumbuhan balaka di Indonesia, maka tumbuhnya balaka di daerah Padang Lawas merupakan suatu hal yang tidak aneh. Hal tersebut karena tumbuhan balaka merupakan salah satu jenis tumbuhan dari famili Euphorbiacae yang hidup dalam tipe ekosistem hutan hujan tropis dataran rendah sebagaimana tipe ekosistem daerah Padang Lawas. Pada masa kini, daerah Padang Lawas tumbuhan balaka tidak saja ditemukan hidup di halaman-halaman candi, tetapi ditemukan pada tempat-tempat lain yang terbuka di daerah ini. Menurut informasi masyarakat pada masa lampau tumbuhan balaka banyak ditemukan hidup di daerah Padang Lawas, dan kemudian banyak yang ditebangi karena adanya pemanfaatan lahan untuk areal perkebunan baik untuk perkebunan kelapa sawit atau perkebunan karet. Oleh karena tumbuhan ini tidak toleran terhadap naungan, maka pada masa kini tumbuhan ini hanya dijumpai pada tempat-tempat yang terbuka yang sinar matahari dapat langsung mencapai tanah seperti di halaman-halaman candi dan di tempat-tempat lain yang tumbuhan semak belukarnya belum begitu tinggi.

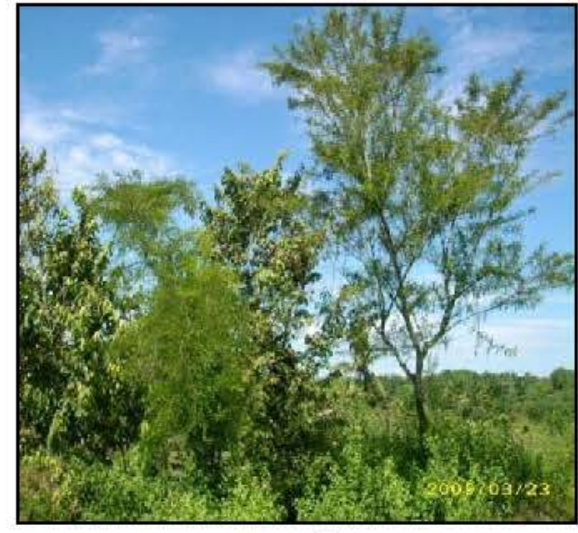

15

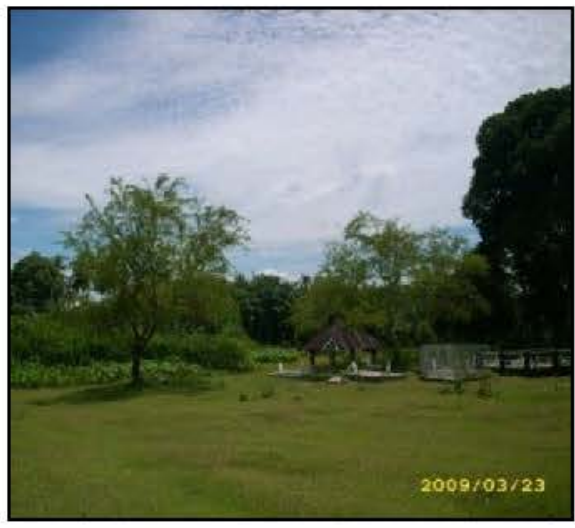

16

Foto 15: Tumbuhan balaka yang diterrukkan hidup pada lingkungan tumbuhan semak belukar. (Dok Axfian, 2009)

Foto 16: Tumbuhan balaka yang ditemukan hidup di lokasi pemakaman masyarakat. (Dok Arfiam, 2009) 
Tumbuhan Balaka (Phyllanthus emblica) merupakan tumbuhan yang sangat bermanfaat bagi manusia karena semua bagian dari tumbuhan ini dapat dimanfaatkan sebagai obat. Buahnya berkhasiat sebagai obat sariawan dan gusi bengkak/bernanah, biji buahnya dapat mengobati asma, demam dan batuk. Adapun daunnya sebagai obat busung lapar, bisul dan eksim. Akarnya dapat dipergunakan sebagai obat batuk berdarah, radang usus, sakit lambung dan tekanan darah tinggi. Pemanfaatan khasiat obat yang terkandung pada bagian-bagian dari tumbuhan balaka oleh masyarakat di daerah Padang Lawas belum diperoleh data yang pasti. Pemanfaatan pohon balaka oleh masyarakat sebatas pemanfaatan kulitnya sebagai campuran bumbu untuk masakan tradisionil mereka yang disebut dengan "Cholat" dan buahnya hanya sekedar untuk dimakan bagi yang menyukainya. Pemanfaatan tumbuhan balaka oleh masyarakat pada masa lampau belum diketahui dengan pasti, tetapi kemungkinan pemanfaatan kayunya sebagai bahan bakar telah dimanfaatakan oleh masyarakat pada masa itu.

\section{PENUTUP}

Berdasarkan hasil penelitian yang dilakukan, maka dapat diketahui bahwa jenis-jenis tumbuhan pamah yang hidup di daerah Padang Lawas, secara umum diketahui bahwa lingkungan vegetasi disusun oleh beraneka jenis tumbuhan yang berasal dari berbagai famili (marga). Dalam lingkungan vegetasi ini juga ditemukan beberapa jenis tumbuhan memanjat dan tumbuhan epihit. Berdasarkan jenis famili tumbuhan, dan ketinggian daerah Padang Lawas yang hanya berkisar 50 - 300 meter dari atas pemukaan laut, maka lingkungan vegetasi di daerah Padang Lawas termasuk dalam tipe ekosistem "Hutan hujan tropik dataran rendah"

Tumbuhan Balaka (Phylanthus emlica) hidup tersebar di Asia Tenggara. Hidup liar di hutan hujan basah, ladang-ladang, dan tempat lain yang berhawa panas. Dari hasil identifikasi dan determinasi yang dilakukan serta sifat hidup dari tumbuhan balaka (Phyllanthus emlica), maka diketahui bahwa jenis tumbuhan balaka merupakan salah satu jenis dari famili tumbuhan yang hidup dalam ekosistem hutan hujan tropis dataran rendah. Merupakan tumbuhan liar yang menyukai daerah berhawa panas atau tempat-tempat terbuka dalam lingkungan hutan hujan tropis.

Di Indonesia jenis Tumbuhan Balaka ditemukan pada beberapa daerah lain dengan nama daerah yang berbeda-beda. Di daerah Melayu dikenal dengan malaka, di Minangkabau dikenal dengan balaka, sedangkan di Sunda orang mengenalnya dengan nama malaka dan di Jawa dikenal dengan Kemloko. Sementara itu di Madura dan Bali disebut dengan mlakah, dan Flores (NTT) dikenal dengan karsinta. Mengamati nama daerah tumbuhan Phyllanthus emlica di daerah Padang Lawas dikenal dengan nama balaka, maka kemungkinan pemberian nama tersebut dipengaruhi oleh pemberian nama tumbuhan tersebut di Minangkabau. 
Dari hasil penelitian ini dapatlah diketahui bahwa Tumbuhan Balaka bukanlah tumbuhan yang hanya dapat hidup di halaman candi di Padang Lawas, tetapi juga ditemukan hidup di daerah lain dengan nama yang berbeda-beda karena tumbuhan tersebut merupakan tumbuhan liar yang hidup dalam lingkungan hutan hujan dataran rendah.

\section{KEPUSTAKAAN}

Anthony J Whitten; Muslimin Mustafa; Greory S Henderson., 1987. Ekologi Sulawesi. Gajah Mada University Press. Yogyakarta.

Butzer,KW.,1972. Environment and Archaelogy. Methuen. London.

Jazanul Anwar, Sengli J Damanik, Nazaruddin Hisyam Dan Anthony J Whitten., 1984 . Ekologi Ekosistem Sumatera. Gajah Mada University Press. Yogyakarta.

J J Afriastini., 1989. Daftar Nama Tumbuhan. Cetakan ke 3. Penebar Swadaya. Jakarta.

Sandy, I Made., 1985. Republik Indonesia: Geografi Regional. Jurusan Geografi, FMIPA. Universitas Indonesia. Jakarta.

Sastrapradja. Didin S; S Adisoemarto; K Kartawinata; Setijati Sastrapradja; Mien A Rifai., 1989. "Keanekaragaman Hayati Indonesia Untuk Kelangsungan Hidup" Makalah dalam Forum Diskusi Keanekaragaman Hayati. 1 Maret 1989. Jakarta

Syahbuddin., 1985. Ekologi Tumbuh-Tumbuhan. Universitas Andalas. Padang.

Suleiman, Satyawati., 1985. "Peninggalan-Peninggalan Purbakala Di Padang Lawas", Amerta No 2, Puslit Arkenas Jakarta.

Sukawati Susetyo. M Fadlan SI., 2006. "Adaptasi Manusia Terhadap Lingkungan: Studi pemukiman kuno di situs Padang Lawas". Laporan Penelitian Arkeologi. Puslitbang Arkeologi Nasional. Jakarta. (tidak diterbitkan)

Tim Penelitian., 2008. "Penelitian Pemukiman Kuno di Situs Candi Sipamutung. Kab Padang Lawas. Sumatera Utara". Laporan Penelitian Arkeologi. Puslitbang Arkeologi Nasional. Jakarta. 
Tjitrosoepomo, Gembong., 1993. Taksonomi Tumbuhan (Spermatophyta), cetakan ke 4. Gajah Mada University Press. Yogyakarta.

Van Steenis, C.G.G.J., 2002. Flora. Cetakan ke 8. PT Pradnya Paramita. Jakarta.

Wisaksono Wijodihardjo M., 1953. IImu Tubuh Tanah. Noordhoff-Kolff. NV. Jakarta. 